\title{
QUANTIFYING CORRUPTION AT A SUBNATIONAL LEVEL
}

\section{Veronika Linhartová, Jolana Volejníková}

\section{Introduction}

Corruption and its potential reduction is a constant topic not only of economic or social science research, but also an issue that plagues governments and citizens alike. This phenomenon is more or less immanent in every social system, regardless of the size and sophistication of the country or culture of the nation. Despite the fact that corruption is not a new phenomenon and a number of foreign and domestic authors have been dealing with this subject for several years, there are still many questions that remain unanswered. The very definition of the term corruption is not yet clear, and different authors define corruption with greater or smaller differences. For more detail, see e.g. [6], [9], [29], [20]. Even the question of whether and how corruption can affect the economic level of a country has never been answered by any literature without controversy. One may thus encounter the view that corruption is "sand in the wheels" of the economy, which impedes economic transactions, as it reduces the security of property rights and contributes to inefficient allocation of resources [23], [28], [24], [17], [13]. On the other hand, there are authors who believe that corruption is precisely what "greases the wheels" of the economy, because it allows individuals to avoid administrative and bureaucratic delays [12], [14], [15], [1], [16]. It can be said, however, that with the existence of adequate legislation, the argument about corruption as "greasing the wheels of the economy" is totally unacceptable.

The issue of quantifying the degree of corruption also raises fierce debate. Considering the fact that bribery and other forms of corruption are illegal in most countries, the people involved make every effort to carefully conceal their actions and revealing corruption is often almost impossible. Even so, there are currently a number of exact procedures that attempt to quantify the level of corruption in a country. Among the best known current indicators of corruption is one example, the CPI (Corruption Perception Index), published annually by Transparency International and the Control of Corruption of the World Bank [27]. A common feature of all currently existing indices of corruption, however, is the fact that all without exception quantify the level of corruption in a country and are therefore not applicable for quantification of corruption at a sub-national level. The authors of this paper argue that the socio-economic development in a country is not homogeneous, and that it can be assumed that a difference exists in the extent of corruption in different regions within the same country. Under this assumption, more corrupt sub-national regions are detrimental to the national evaluation of corruption in a country as a whole. The fact that the distribution of corruption in a country is not homogenous was confirmed by authors [2] and [5] in their studies of Italian regions. The level of corruption in the sub national breakdown as reported by these authors was very diverse and its analysis can help explain the differences in the different economic performance of the regions. It can be noted, however, that the study of the Italian authors is unique and finding another study on the quantification of regional levels of corruption, or its impact on the region, is virtually impossible. From this it is clear that the issue of quantifying corruption and its consequences at the regional level is a topic that deserves more attention. There are several reasons to consider these issues. Perhaps the strongest is that if corruption is indeed one of the variables that are degrading the performance of economies, the elimination of corruption in certain regions may just be the key to removing regional economic disparities and thereby increasing the economic performance of the country. Analysing regional corruption may also lead to the creation of direct regional anti-corruption 
initiatives that can bring about reductions in the national level of corruption. In general terms, a sub-national resolution in terms of the degree of corruption could bring a new dimension to traditional theories of regional disparities.

The main objective of this article is formulated in the context of the above considerations. It contains a design for a method of quantifying the extent of corruption at the level of regional cohesion. The proposed method is then verified and applied to individual regions of the Member States and candidate States of the European Union. Using the proposed method it is possible to evaluate the current state of corruption in the evaluated regions, to mutually compare the regions, to determine the degree of deviation from the "surface" level of national corruption and simultaneously determine the degree of variability in the extent of corruption within the country.

The text of this article presents the proposed method of quantifying the regional level of corruption verified using Kendall's coefficient of concordance for further use. Verification of the proposed method is carried out at a national and regional level. Methods at the national level are verified by comparing the evaluation of the newly proposed method to the evaluation of existing corruption indices. This will determine the level of agreement between the already established indices and the newly proposed method. The methods are verified at the regional level using police statistics on recorded corruption offences. After the method is verified, the level of corruption in the various regions is calculated. Special attention is paid to quantifying the extent of corruption in the regions of the Czech Republic. Calculating the level of corruption in the Czech regions will identify those regions which are more affected by corruption than others and would thus worsen the national evaluation of the Czech Republic within the standard published indices of corruption.

\section{Proposal for a Method of Quantifying the Extent of Corruption at a Sub-National Level}

Due to the absence of any method for determining corruption in a more or less affected sub-national region, the next section will present a method for quantifying corruption at a sub-national level. The design of this method is based on the construction of the European Quality of Government Index developed by the European Commission together with The Qua- lity of Government Institute. Corruption is understood here in accordance with the definition of Nye, who describes corruption as "behaviour that deviates from the formal duties of a public role because of private-regarding wealth or status gains"[20]. This definition focuses on the abuse of public power, and somewhat ignores corruption in the private sector, which of course also exists. Most existing studies, however, have focused on corruption in the public sector, as the consequences of misuse of public power impact the broad mass of taxpayers and the country as such.

\subsection{The European Quality of Government Index}

The European Quality of Government Index (EQI) was created to quantify the quality of public administration at a regional level. The index so far been developed twice; in 2010 and 2013. 27 EU Member States were included in the EQI in 2010. In 2013, 28 EU Member States are included as well as the Candidate States Turkey and Serbia; in total 30 countries. The European Commission plans to construct EQI regularly every three years.

In addition to the national evaluation of the quality of governance, the resulting EQI also takes note of the evaluation of regional administration using regional data which the European Commission has drawn up for the needs of constructing the EQI. The EQI thus consists of two main parts:

The first part of the EQI takes into account the national government level, which is represented by the Worldwide Governance Indicators (WGI) of the World Bank. Of the six pillars of the quality of governance, the European Commission chose four for the construction of the EQI: Voice and Accountability (GM1), Government Effectiveness (GM3), Rule of Law (GM5) Control of Corruption (GM6) [4], [26], [11].

The second part of the EQI, which takes into account the regional level of governance, was compiled by the European Commission on the basis of a unique regional survey, conducted for the sole purpose of creating a Regional indicator of government quality, which would take into account regional aspects in the final construction of the EQI.

This unique research registered in the first construction of the EQI was executed in 172 NUTS II regions in 18 countries of the Eu- 
ropean Union in 2010 (from the remaining 9 countries of the European Union only data at the national level was included). The research includes altogether 181 regional units. Data was obtained by means of surveying more than 33,000 inhabitants. The all-European regional research was conducted from $15^{\text {th }}$ December 2009 to $1^{\text {st }}$ February 2010 by means of telephone interviews with respondents older than 18 years and in the local language.

In the second construction of EQI, it was executed in 206 NUTS regions in 24 countries of the European Union in 2013 (from the remaining 7 countries of the European Union only data at the national level was included). The research includes altogether 213 regional units. Data was obtained by means of research of more than 85,000 inhabitants.

The resulting regional quality of administration indicator reflects the actual experience of respondents with the use of individual public services, thus the quality of governance in the region is evaluated as it is perceived by its inhabitants; i.e., the recipients of public administration. The Regional indicator of government quality is composed of 16 separate indicators relating to the quality of administration in a particular region. These 16 indicators were developed based on 16 questions (The list of ques- tions is available at http://www.qog.pol.gu.se/ data/datadownloads/qogeuregionaldata/.) developed in accordance with the pillars arising from the methodology of the WGI: Voice and Accountability, Government Effectiveness, Rule of Law and Control of Corruption. In order to capture the most important sub-national differences, questions were focused on three public services that are often funded or administered at sub-national levels. Each of the four pillars mentioned thus involves issues relating to education, health care and law enforcement in the region. With a focus on these three services, respondents were asked to assess these public services with regard to the three fundamental concepts of quality administration - quality, impartiality and corruption. These three concepts are the pillars of the resulting regional indicator of quality government. Data is aggregated three times using a simple average. First is the creation of the average values of responses to the questions. This will create 16 indicators for each region. Then these 16 values are aggregated into three defined pillars - quality, impartiality and corruption. Finally, these three pillars are aggregated into a single numerical Regional quality of administration indicator. A simple diagram of the formation of the Regional indicator of government quality is shown in Figure 1.

\section{Fig. 1: Approach to creating a Regional Indicator of Government Quality}

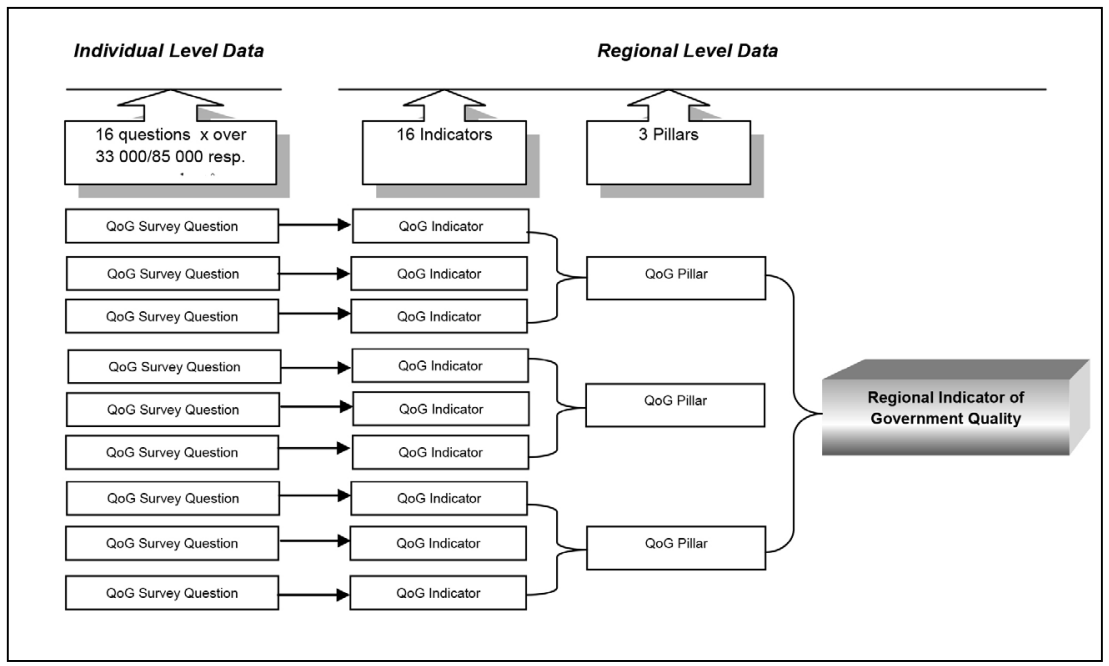


Thus in its final form, the resulting EU Quality of Government Index enriches the national evaluation of quality of administration created by the World Bank (WGI) on a regional scale (Regional indicator of government quality).

The final form of the construction of the EQI is as follows:

$$
\begin{aligned}
& E Q I_{\text {regionXincountryY }}=W G I_{\text {countryY }}+ \\
& +\left(R_{\text {qogregionXincountryY }}-C R_{\text {qogcountryY }}\right),
\end{aligned}
$$

where $E Q I_{\text {regionXincountryy }}$ is the final European Quality of Government Index in the region of a given country,

$W G I_{\text {country }}$ is the national average of the above four Worldwide Governance Indicators for each country,

$R_{\text {qogregionXincountryY }}$ is the score from a regional survey; thus the Regional indicator of government quality,

$C R_{\text {gogcountryy }}$ is the regional survey of all regions in the country weighted by the proportion of the population of each region to the national population of the country.

The EQI has so far been calculated twice; once in 2010 and in 2013. Member States of the EU-28, Turkey and Serbia, were included in the calculation.

\subsection{Proposal for a Regional Index of Corruption}

It is apparent that the resulting EQI, as it was compiled by the European Commission together with The Quality of Government Institute, provides the opportunity to pursue a quantification of corruption at a sub-national level, which had not previously been practically possible. The primary modifications of the already created EQI can create a modified index, which, of all the components of quality government, takes into account only corruption; it therefore takes into account only the indicator Control of Corruption in the national evaluation and the indicator Pillars of Corruption in the regional evaluation. Based on this modified methodology of the EQI composition, the modified method of calculating EQI can then be applied only for the purpose of quantifying corruption in the cohesion regions.

The resulting Regional Index of Corruption $(\mathrm{RIC})$ is then calculated based on the formula:

$$
\begin{aligned}
& R I C_{\text {regionXincountryY }}=\mathrm{CC}_{\text {countryY }}+ \\
& +\left(P C_{\text {qogregionXincountryY }}-C P C_{\text {qogcountryY }}\right),
\end{aligned}
$$

where $R I C$ is the resulting Regional Index of Corruption for each region of a given country,

$C C_{\text {countryy }}$ is the national indicator value of Control Of Corruption (GM6) from the Worldwide Governance Indicators,

$P C_{\text {qogregionXincountryY }}$ is the score from a regional survey focused on corruption, thus Pillar of Corruption,

$C P C_{\text {qogcountryy }}$ is the value for the Pillar of Corruption from the regional survey of all regions in a country weighted by the proportion of the population in each region on the national population of the country.

Composite indicators often evoke a number of questions relating to their composition and weighting of the individual indicators entering into a composite indicator. There were created tens of aggregated indicators at the time when composite indicators reached a rapid expansion. Most of them, unfortunately, were not built on correct statistical basis [25]. Because of these errors composite indicators failed to meet expectations, which were inserted into them, sparking concerns among their users and negatively affected trust in composite indicators in general. The credibility of these indicators is mainly related to the accuracy of data, based on which they are constructed and the methodology by which they are constructed. Number of composite indicators is constructed by reputable international institution. Such indicators can get known and respected easier and earlier. However, although composite indicators are designed very carefully and statistical requirements have been met, their acceptation is always dependent on bargaining and how they are accepted by experts and public. Acceptation of aggregated indicators mostly depends on how they meet the original goal, i.e. whether measure what they should and the subsequent acceptance of their users. Gaining legitimacy and trust of users is a gradual process.

In the case of constructing indicator EQI was by the European Commission used an equal weighting of entering variables. With respect to author's proposed RIC is a modification of EQI, authors of the article do not consider important further weighting of variables entering into RIC.

\section{Applying the Proposed Regional Index of Corruption}

The Regional Index of Corruption (hereinafter $\mathrm{RIC}$ ) is applied and tested first at the national 
level, then at the level of the cohesion regions. From the resulting values, the individual regions can be mutually compared and regions can be identified which are more or less affected by corruption. Table 1 shows the resulting ranking of countries in the newly created RIC for the years 2010 and 2013. Countries in the segmented EQI 2013 are included; thus there are a total of 30 countries. The higher the value of the RIC, the better is the evaluation of the country's RIC. In the evaluation of the RIC between 2010 and 2013, it was found that the new Member States and candidate States of the European Union are at the very bottom of the list of countries evaluated. Conversely, the Nordic countries were evaluated as the least affected by corruption.

\section{Tab. 1: Regional Index of Corruption for 2010 and 2013}

\begin{tabular}{|c|c|c|c|c|c|}
\hline NUTS I & RIC 2010 & Ranking & NUTS I & RIC 2013 & Ranking \\
\hline DK & 1.811919 & 1 & DK & 1.841393 & 1 \\
\hline $\mathrm{FI}$ & 1.740486 & 2 & SE & 1.559288 & 2 \\
\hline SE & 1.516722 & 3 & $\mathrm{FI}$ & 1.555572 & 3 \\
\hline $\mathrm{NL}$ & 1.438868 & 4 & LU & 1.493145 & 4 \\
\hline LU & 1.261475 & 5 & $\mathrm{NL}$ & 1.479409 & 5 \\
\hline AT & 1.142543 & 6 & $\mathrm{DE}$ & 0.932501 & 6 \\
\hline IE & 0.948732 & 7 & UK & 0.779821 & 7 \\
\hline $\mathrm{DE}$ & 0.917613 & 8 & $\mathrm{BE}$ & 0.749709 & 8 \\
\hline UK & 0.830591 & 9 & IE & 0.726454 & 9 \\
\hline FR & 0.488344 & 10 & $\mathrm{FR}$ & 0.703595 & 10 \\
\hline $\mathrm{BE}$ & 0.415918 & 11 & AT & 0.609217 & 11 \\
\hline $\mathrm{CY}$ & 0.322032 & 12 & PT & 0.168304 & 12 \\
\hline ES & 0.157165 & 13 & ES & 0.131936 & 13 \\
\hline MT & 0.083101 & 14 & EE & -0.0212 & 14 \\
\hline PT & 0.029269 & 15 & $\mathrm{SI}$ & -0.05617 & 15 \\
\hline $\mathrm{SI}$ & -0.07815 & 16 & $\mathrm{CY}$ & -0.07266 & 16 \\
\hline EE & -0.12856 & 17 & MT & -0.1372 & 17 \\
\hline LV & -0.67118 & 18 & PL & -0.56423 & 18 \\
\hline LT & -0.70428 & 19 & $\mathrm{HU}$ & -0.76712 & 19 \\
\hline $\mathrm{HU}$ & -0.71697 & 20 & $\mathrm{CZ}$ & -0.7947 & 20 \\
\hline $\mathrm{PL}$ & -0.76271 & 21 & SK & -0.85981 & 21 \\
\hline SK & -0.81496 & 22 & $\mathrm{LT}$ & -0.86415 & 22 \\
\hline $\mathrm{CZ}$ & -0.85541 & 23 & LV & -0.92744 & 23 \\
\hline IT & -0.87991 & 24 & IT & -1.05754 & 24 \\
\hline GR & -1.06275 & 25 & TR & -1.08985 & 25 \\
\hline TR & -1.08395 & 26 & HR & -1.14626 & 26 \\
\hline $\mathrm{HR}$ & -1.23592 & 27 & GR & -1.38318 & 27 \\
\hline RO & -1.37328 & 28 & RO & -1.39001 & 28 \\
\hline $\mathrm{RS}$ & -1.55004 & 29 & $B G$ & -1.43259 & 29 \\
\hline BG & -1.55089 & 30 & RS & -1.46287 & 30 \\
\hline
\end{tabular}


By using Statistica 12, graphic models were created of the variability of RIC values in individual countries for the years 2010 and 2013. The box plots use the method of min-max comparison and show the range of RIC values marking the best and the worst of the regions evaluated in the country. On the $x$-axis are plotted the countries evaluated; on the $y$-axis are the resulting values of the RIC in a given year. The range of values is complemented by the final value of the RIC of the country, which is represented by an asterisk. Figure 2 shows the range of RIC values for 2010 in the thirty countries evaluated. Definitely the greatest variability in the assessment of corruption is to be found in the Italian regions. Italian respondents answered questions regarding the impact of corruption on their area with great differences, and perceived corruption very differently depending on which region they live. The most corrupt Italian region, based on the results of the RIC from 2010, is the Campania region
(ITF3), while the best ratings were achieved in the Umbria region (ITE2). A high variability was also observed in Romania, France and the Netherlands. Rating corruption at the national level can be particularly misleading for these countries. In the Czech Republic, a middle variability of RIC values was recorded. The top rated region is Jihozápad (Southwest) (CZ03) with a value of -0.9346 and the worst rating is the capital city of Prague (CZ01) with a value of -1.9878 .

In the evaluation of RIC in 2010, the NUTS II regions which placed best were the Dutch region of Groningen (NL11) with a value of 2.8867. The best ratings in 2010 were achieved generally by Dutch, Danish, Finnish and Swedish regions. In contrast, at the other end of the ranking were Romanian, Italian and Bulgarian regions.

Definitely the worst ranking among the NUTS II regions was the Romanian region of Bucharest (RO32) with a value of -2.7491 .

\section{Fig. 2: Box Graph of Values for the Regional Index of Corruption for 2010}

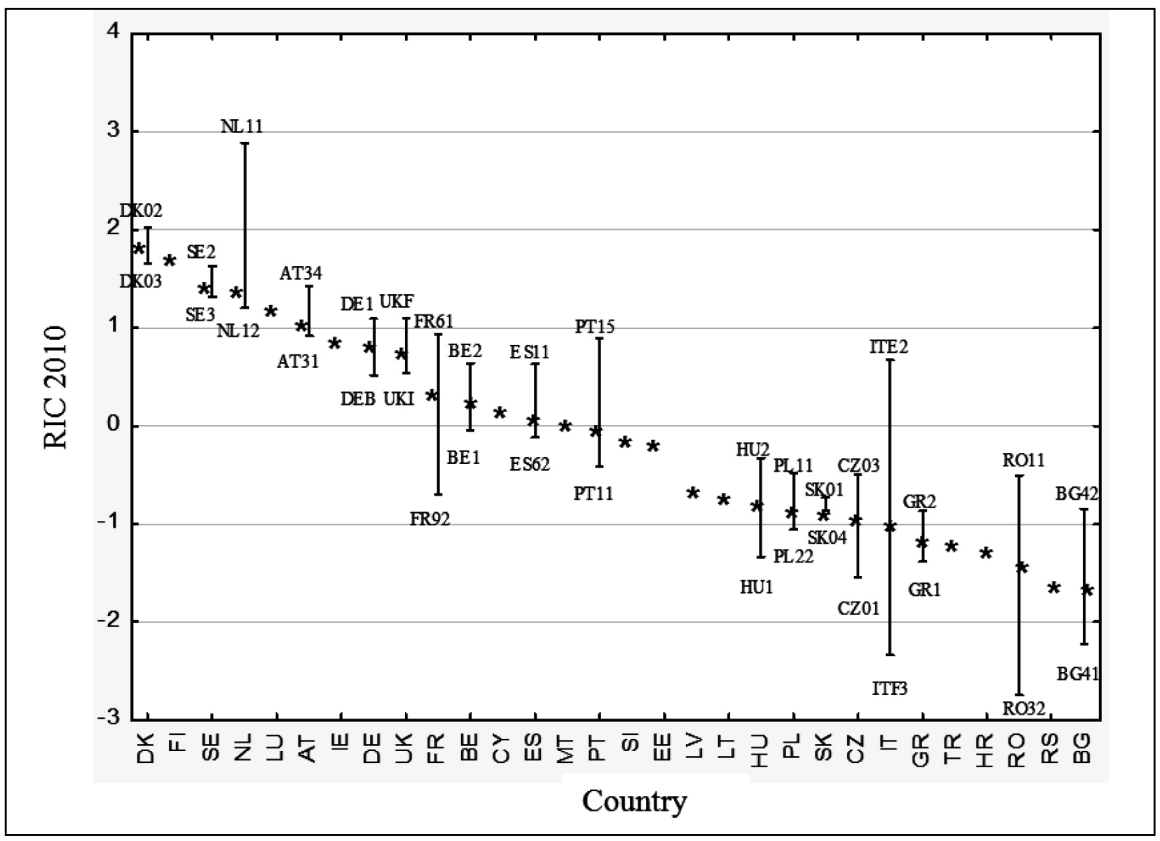


Figure 3 shows the range of values of RIC for 2013. In 2013, the region with the lowest level of corruption was the Finnish region of Aland (FI20) with a value of 2.3932. On the other hand, the most corrupt region of the European Union was the Bulgarian region of Yugozapaden (BG41) with a value of -2.5237 . A high variability of data in 2013 was found again in Italy, as well as Bulgaria, Turkey and Romania. In these countries, the inhabitants of regions had different opinions on the impact of corruption in their area and the corruption assessment may not reflect the current situation in some regions. In contrast, in Danish, Swedish, Irish and Croatian regions only very small deviations, were detected in the values of RIC of 2013 and evaluation of the national level of corruption relevantly reflects the evaluation of the regions. Within the Czech Republic, in 2013 the best region evaluated in terms of corruption was Jihozápad (Southwest) (CZ03) with a value of -0.5694 and the most corrupt region was Severozápad (Northwest) (CZ04) with a value of -1.2304 .

\section{Fig. 3: Box Graph of Values for the Regional Index of Corruption for 2013}

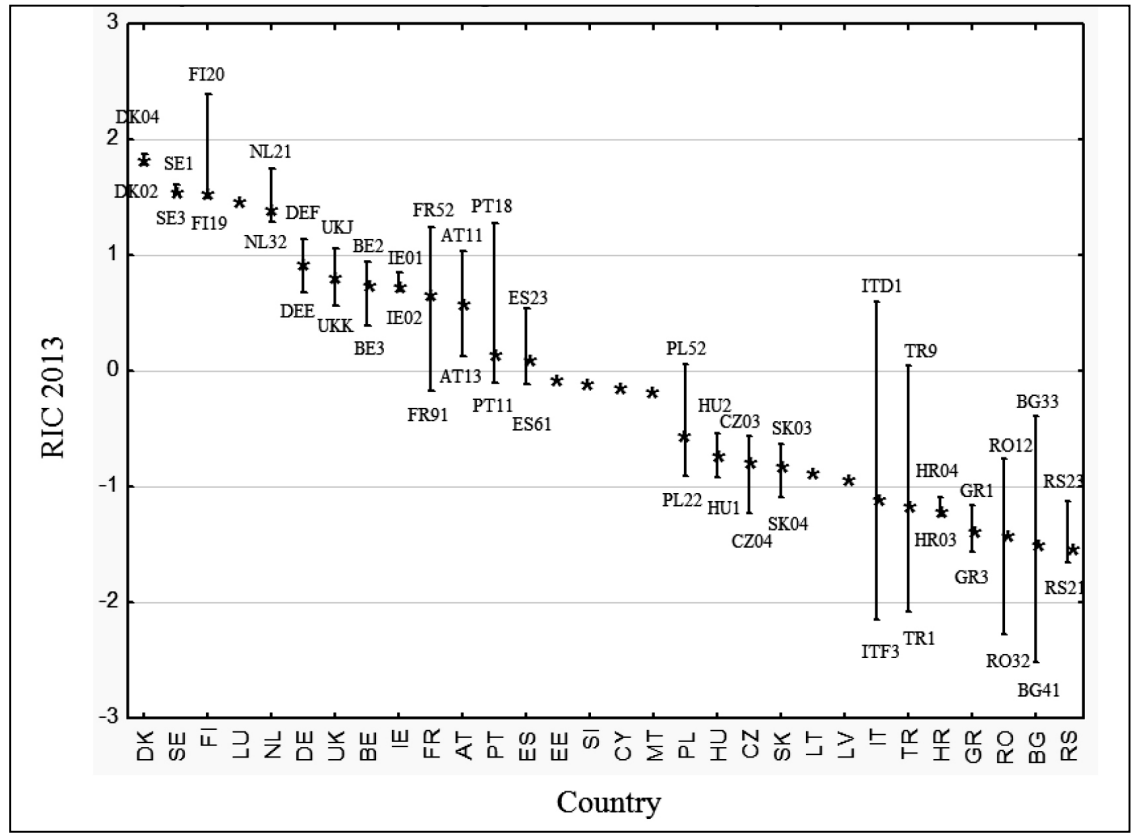

Source: Author's own work

The resulting RIC values demonstrate that some European Union countries show a very high degree of variability in the regional level of corruption. This confirms the assumption that existing indices evaluating the national level of corruption can ultimately overestimate the regions more affected by corruption and underestimate the less corrupt. Definitely the greatest variability of the data evaluated in both years was demonstrated in the Italian regions. In Italy, as one of the smaller countries, several studies on corruption have been conducted in various Italian regions. The authors [2] and [5] in their studies agree that the variability of the degree of corruption in the Italian regions is very high and in this country there are regions with very high levels of corruption, but also regions with much lower levels of corruption. By applying the proposed Regional Corruption Index (RIC), not only were the conclusions of the authors confirmed regarding the Italian regions, but this conclusion is demonstrated in the majority of countries surveyed. 


\subsection{Verifying the Proposed Method}

The proposed method of quantifying the degree of corruption at the regional level is subsequently verified at national and regional level. Kendall's coefficient of concordance can be used for mathematical verification of the conformity of the assessment methods for the proposed RIC and existing indexes. This is a non-parametric method of mathematical statistics which is primarily used to assess the conformity of individual evaluators. The value of the coefficient varies between 0 (no agreement) and 1 (complete agreement) [10].

\subsubsection{Verifying Method at the National Level}

In order to compare evaluations at the national level, two presently existing indices are selected which measure the degree of corruption in the country. These are indices that focus exclusively on quantifying the national level of corruption. The selected corruption indicators are the Corruption Perceptions Index (CPI) of Transparency International and the Control of Corruption (CC) of the World Bank [11], [27]. Given that data from the Regional government quality indicator, which was used for the construction of the RIC, has been collected among respondents since 2009 and the data of the World Bank to evaluate the situation at the national level was drawn upon in 2008 , it is appropriate, in assessing conformity of the ratings, to take into account not only data for 2010. To compare the resulting values of RIC for 2010, a time range of existing indices were selected for the years 2008-2010, which take into account the entire time period during which the data was collected for the RIC. To verify the agreement of the assessment of RIC for 2013, the time range 2011 to 2013 was chosen.

Table 2 presents the resulting calculation of Kendall's coefficient of concordance ranking countries according to the RIC in 2010 and the CPI and CC from 2008 to 2010 and to the RIC 2013 and the CPI and the CPI and CC from 2011 to 2013 as evaluated by the program Statistica 12. Kendall's coefficient of concordance assessing the order of the selected indices reaches around $98 \%$. The RIC itself with each of the chosen indices for each year corellates in all cases at least at a level of $95 \%$.

High values of the coefficients of concordance in both years indicate that the proposed RIC ranks countries in terms of their corruption very similarly to the currently used indices of corruption. These conclusions of Kendall's coefficient of concordance verify the possibility of using the RIC.

\begin{tabular}{c|c|c|c|c|c|c|c|c}
\multirow{4}{*}{ Tab. 2: } & \multicolumn{1}{c}{$\begin{array}{l}\text { Kendall's Coefficients of Concordance for Regional Index of Corruption } 2010 \\
\text { and 2013 - Part 1 }\end{array}$} \\
\cline { 2 - 9 } Variable & \multicolumn{3}{|c|}{ Kendall's coefficient for RIC 2010 } & \multicolumn{3}{c}{ Kendall's coefficient for RIC 2013 } \\
\cline { 2 - 9 } & \multicolumn{3}{|c|}{ Avg. value r variables-30, no. of indices-7) } & \multicolumn{3}{c}{ (no. of variables-30, no. of indices-6) } \\
\cline { 2 - 9 } & $\begin{array}{c}\text { Average } \\
\text { (ranking) }\end{array}$ & $\begin{array}{c}\text { Total } \\
\text { (ranking) }\end{array}$ & Average & Deviation & $\begin{array}{c}\text { Average } \\
\text { (ranking) }\end{array}$ & $\begin{array}{c}\text { Total } \\
\text { (ranking) }\end{array}$ & Average & Deviation \\
\hline AT & 6.85714 & 48.0000 & 6.85714 & 0.89974 & 10.33333 & 62.0000 & 10.16667 & 1.602082 \\
\hline BE & 10.28571 & 72.0000 & 10.28571 & 0.48795 & 8.08333 & 48.5000 & 8.00000 & 0.632456 \\
\hline BG & 28.71429 & 201.0000 & 28.57143 & 1.13389 & 28.58333 & 171.5000 & 28.50000 & 0.836660 \\
\hline CY & 13.57143 & 95.0000 & 13.42857 & 1.39728 & 13.66667 & 82.0000 & 13.66667 & 1.861899 \\
\hline CZ & 20.50000 & 143.5000 & 20.42857 & 1.51186 & 21.25000 & 127.5000 & 21.00000 & 1.095445 \\
\hline DE & 7.35714 & 51.5000 & 7.28571 & 0.95119 & 6.00000 & 36.0000 & 6.00000 & \\
\hline DK & 1.14286 & 8.0000 & 1.00000 & & 1.16667 & 7.0000 & 1.00000 & \\
\hline EE & 14.71429 & 103.0000 & 14.57143 & 2.22539 & 13.33333 & 80.0000 & 13.33333 & 1.032796 \\
\hline ES & 13.85714 & 97.0000 & 13.85714 & 0.89974 & 13.66667 & 82.0000 & 13.66667 & 1.211060 \\
\hline FI & 2.42857 & 17.0000 & 2.28571 & 0.75593 & 2.41667 & 14.5000 & 2.16667 & 0.983192 \\
\hline
\end{tabular}




\begin{tabular}{|c|c|c|c|c|c|c|c|c|}
\hline ab. 2: & \multicolumn{8}{|c|}{$\begin{array}{l}\text { Kendall's Coefficients of Concordance for Regional Index of Corruption } 2010 \\
\text { and } 2013 \text { - Part } 2\end{array}$} \\
\hline \multirow{4}{*}{ Variable } & \multicolumn{4}{|c|}{ Kendall' s coefficient for RIC 2010} & \multicolumn{4}{|c|}{ Kendall' s coefficient for RIC 2013} \\
\hline & \multicolumn{4}{|c|}{ (no. of variables-30, no. of indices-7) } & \multicolumn{4}{|c|}{ (no. of variables-30, no. of indices-6) } \\
\hline & \multicolumn{4}{|c|}{ Avg. value $r=0.97501$} & \multicolumn{4}{|c|}{ Avg. value $r=0.98355$} \\
\hline & $\begin{array}{l}\text { Average } \\
\text { (ranking) }\end{array}$ & $\begin{array}{c}\text { Total } \\
\text { (ranking) }\end{array}$ & Average & Deviation & $\begin{array}{l}\text { Average } \\
\text { (ranking) }\end{array}$ & $\begin{array}{c}\text { Total } \\
\text { (ranking) }\end{array}$ & Average & Deviation \\
\hline FR & 10.71429 & 75.0000 & 10.71429 & 0.48795 & 10.00000 & 60.0000 & 10.00000 & 0.632456 \\
\hline GR & 26.07143 & 182.5000 & 25.85714 & 2.03540 & 28.33333 & 170.0000 & 28.33333 & 1.366260 \\
\hline HR & 26.42857 & 185.0000 & 26.42857 & 0.78679 & 25.08333 & 150.5000 & 24.83333 & 1.329160 \\
\hline $\mathrm{HU}$ & 19.28571 & 135.0000 & 19.28571 & 1.11269 & 19.50000 & 117.0000 & 19.50000 & 0.547723 \\
\hline IE & 6.85714 & 48.0000 & 6.71429 & 0.75593 & 33333 & 56.0000 & 9.16667 & 0.408248 \\
\hline IT & 23.85714 & 167.0000 & 23.85714 & 1.57359 & 25.41667 & 152.5000 & 25.33333 & 1.211060 \\
\hline LT & 21.78571 & 152.5000 & 21.57143 & 2.99205 & 19.91667 & 119.5000 & 19.83333 & 1.940790 \\
\hline LU & 5,00000 & 35.0000 & 5.00000 & & 4.66667 & 28.0000 & 4.66667 & 0.516398 \\
\hline LV & 21.78571 & 152.5000 & 21.57143 & 1.90238 & 22.41667 & 134.5000 & 22.1666 & 0.983192 \\
\hline MT & 16.00000 & 112.0000 & 16.00000 & 1.41421 & 17.16667 & 103.0000 & 17.16667 & 1.329160 \\
\hline $\mathrm{NL}$ & 3.92857 & 27.5000 & 3.85714 & 0.37796 & 4.33333 & 26.0000 & 4.33333 & 0.516398 \\
\hline $\mathrm{PL}$ & 19.71429 & 138.000 & 19.57143 & 2.22539 & 17.33333 & 104.0000 & 17.33333 & 1.211060 \\
\hline PT & 14.57143 & 102.0000 & 14.57143 & 1.81265 & 14.00000 & 84.0000 & 14.00000 & 1.673320 \\
\hline RO & 28.14286 & 197.0000 & 28.00000 & 0.81649 & 27.41667 & 164.5000 & 27.33333 & 1.211060 \\
\hline $\mathrm{RS}$ & 29.64286 & 207.5000 & 29.57143 & 0.53452 & 29.41667 & 176.5000 & 29.33333 & 0.816497 \\
\hline SE & 2.50000 & 17.5000 & 2.42857 & 0.78680 & 2.41667 & 14.5000 & 2.33333 & 0.516398 \\
\hline SI & 14.28571 & 100.0000 & 14.14286 & 2.11570 & 16.08333 & 96.5000 & 16.00000 & 0.894427 \\
\hline SK & 21.64286 & 151.5000 & 21.42857 & 1.13389 & 23.33333 & 140.0000 & 23.16667 & 1.722401 \\
\hline TR & 24.42857 & 171.0000 & 24.28571 & 1.25357 & 23.08333 & 138.5000 & 22.83333 & 1.722401 \\
\hline UK & 8.92857 & 62.5000 & 8.85714 & 0.37796 & 7.25000 & 43.5000 & 7.16667 & 0.408248 \\
\hline
\end{tabular}

Source: Author's own work

\subsubsection{Verifying the Proposed Methods at the Regional Level}

At present, virtually the only possible way to verify the proposed method at the regional level is to compare RIC with statistics of corruption offences in the regions of the Czech Republic. According to official statistics of the Ministry of the Interior and the of the Czech National Police, however, only recorded cases of corruption can be traced, whose number is based on the activity of the state bodies. The strategy of the government in the fight against corruption for the period 2013-2014 indicates that corruption in the Czech Republic has a high degree of latency and only a few cases have been uncovered [18]. According to the Government Programme for Combating Corruption of the Czech Republic, only one percent of corruption offences have been uncovered [19]. The actual number of these crimes that have occurred in recent years is likely to be much higher [21]. For the purposes of distinguishing the regions on the basis of corruption, without the need for a precise quantification, this tool is usable.

In order to verify the Regional Corruption Index, the following corruption offences are used, related to corruption in public administration, which is defined by the Criminal 
Code: accepting bribes (§ 331), bribery (§ 332) and indirect bribery ( $\S 333$ ), abuse of power of officials (§ 329$)$, obstruction of official duties of a person by negligence ( $\S 330$ ). Given that the most risky area is currently regarded to be the redistribution of public funds through procurement and auction sales, the analysis also includes the offences of manipulation of public procurement and public tenders ( $\S 257$ ) and actions against public auctions ( $(258)$.

The following Table 3 shows the results of Kendall's coefficient of concordance for the RIC of 2010 and the evaluation of the regions on the basis of crimes recorded in 2008-2010. The value of Kendall's coefficient in all the years in question has a value of at least about $74 \%$, which indicates a statistically significant concordance between the assessment of the regions based on the RIC in 2010 and rated based on police statistics. Verification of conformity conclusions of RIC for 2013 and statistics of corruption offences recorded in the years 2011 to 2013 is shown in Table 4. The evaluation of RIC from 2013 coincides with police statistics of this period by at least $40 \%$.

Verification of data at the regional level is not as clear as with national data; however, the assessment of the regions on the basis of corruption offences and under the proposed Regional Corruption Index (RIC) has also been shown to coincide. The observed values of the assessed coefficients of concordance rank the regions based on the evaluation of police statistics and the proposed RIC confirms the predicted use of this index as a tool for defining more and less corrupt areas at the regional level.

\begin{tabular}{|c|c|c|c|c|c|c|c|c|c|c|c|c|}
\hline Tab. 3: & \multicolumn{12}{|c|}{$\begin{array}{l}\text { Kendall's Coefficients of Concordance for the Regional Index of Corruption } \\
2010 \text { and corruption crimes in 2008-2010 }\end{array}$} \\
\hline \multirow{4}{*}{ Variable } & \multicolumn{4}{|c|}{ Corruption Crimes 2008} & \multicolumn{4}{|c|}{ Corruption Crimes 2009} & \multicolumn{4}{|c|}{ Corruption Crimes 2010} \\
\hline & \multicolumn{4}{|c|}{ (no. of variables-8 no. of indices-2) } & \multicolumn{4}{|c|}{ (no. of variables-8, no. of indices-2) } & \multicolumn{4}{|c|}{ (no. of variables-8, no. of indices-2) } \\
\hline & \multicolumn{4}{|c|}{ Avg. value $r=0.73810$} & \multicolumn{4}{|c|}{ Avg. value $r=0.85714$} & \multicolumn{4}{|c|}{ Avg. value $r=0.76190$} \\
\hline & 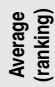 & ॠ & 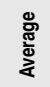 & 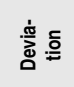 & 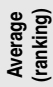 & 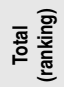 & 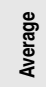 & 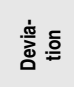 & 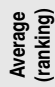 & ๙ & 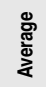 & 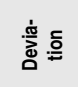 \\
\hline Prague & 1.00 & 2.00 & 1.00 & & 1.00 & 2.00 & 1.00 & & 1.00 & 2.00 & 1.00 & \\
\hline Severozápad & 2.00 & 5.00 & 2.00 & 0.70711 & 3.00 & 6.00 & 3.00 & & 2.00 & 5.00 & 2.00 & 0.70711 \\
\hline Středni Čechy & 4.00 & 9.00 & 4.00 & 0.70711 & 4.00 & 9.00 & 4.00 & 0.70711 & 4.00 & 8.00 & 4.00 & \\
\hline Jihovýchod & 2.00 & 5.00 & 2.00 & 0.70711 & 2.00 & 4.00 & 2.00 & & 3.00 & 7.00 & 3.00 & 2.12132 \\
\hline Severovýchod & 5.00 & 11.00 & 5.00 & 2.12132 & 5.00 & 11.00 & 5.00 & 2.12132 & 6.00 & 13.00 & 6.00 & 0.70711 \\
\hline MorSlez & 6.00 & 13.00 & 6.00 & 2.12132 & 5.00 & 11.00 & 5.00 & 0.70711 & 4.00 & 8.00 & 4.00 & 1.41421 \\
\hline Jihozápad & 7.00 & 15.00 & 7.00 & 0.70711 & 8.00 & 16.00 & 8.00 & & 7.00 & 15.00 & 7.00 & 0.70711 \\
\hline $\begin{array}{l}\text { Střední } \\
\text { Morava }\end{array}$ & 6.00 & 12.00 & 6.00 & & 6.00 & 13.00 & 6.00 & 0.70711 & 7.00 & 14.00 & 7.00 & 1.414211 \\
\hline
\end{tabular}

Source: Author's own work

\section{Quantifying the Degree of Corruption in the Regions of the Czech Republic}

The development of RIC values for 2010 and 2013 for the regions of the Czech Republic in Table 5 show particularly evident significantly worse ratings for the regions Severozápad and Moravskoslezsko between these periods. Conclusions of the RIC may support the conclusions of many organisations that deal with this issue, such. For example, according to the non-profit organisation Oživení, Moravskoslezsko is one of the worst regions evaluated, both in terms of transparency of public procurement, and in terms of the risk of conflict of interest. According to research by the Industry and Transport Association, whose aim was to highlight the main issues of the business environment, companies and business owners consider corruption to be serious and a complication to their business activities mainly in the Severozápad region [22]. 


\begin{tabular}{|c|c|c|c|c|c|c|c|c|c|c|c|c|}
\hline Tab. 4: & \multicolumn{12}{|c|}{$\begin{array}{l}\text { Kendall's Coefficients of Concordance for the Regional Index of Corruption } \\
2013 \text { and corruption crimes in } 2011-2013\end{array}$} \\
\hline \multirow{4}{*}{ Variable } & \multicolumn{4}{|c|}{ Corruption Crimes 2011} & \multicolumn{4}{|c|}{ Corruption Crimes 2012} & \multicolumn{4}{|c|}{ Corruption Crimes 2013} \\
\hline & \multicolumn{4}{|c|}{ (no. of variables-8 no. of indices-2) } & \multicolumn{4}{|c|}{ (no. of variables -8, no. of indices-2) } & \multicolumn{4}{|c|}{ (no. of variables -8, no. of indices-2) } \\
\hline & \multicolumn{4}{|c|}{ Avg. value $r=0.40476$} & \multicolumn{4}{|c|}{ Avg. value $r=0.71429$} & \multicolumn{4}{|c|}{ Avg. value $r=0.64286$} \\
\hline & 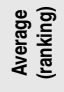 & 효유 & 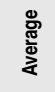 & 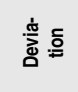 & 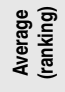 & 효을 & 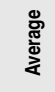 & 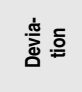 & 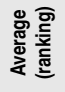 & 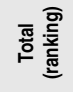 & 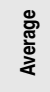 & 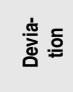 \\
\hline Prague & 2.00 & 4.00 & 2.00 & 1.41421 & 2.00 & 4.00 & 2.00 & 1.41421 & 2.00 & 4.00 & 2.00 & 1.41421 \\
\hline Severozápad & 2.00 & 4.00 & 2.00 & 1.41421 & 1.00 & 3.00 & 1.00 & 0.70711 & 1.00 & 3.00 & 1.00 & 0.70711 \\
\hline Střední Čechy & 3.00 & 6.00 & 3.00 & 1.41421 & 3.00 & 7.00 & 3.00 & 0.70711 & 3.00 & 7.00 & 3.00 & 0.70711 \\
\hline Jihovýchod & 5.00 & 10.00 & 5.00 & 1.41421 & 5.00 & 10.00 & 5.00 & 1.41421 & 5.00 & 10.00 & 5.00 & 1.41421 \\
\hline Severovýchod & 7.00 & 14.00 & 7.00 & & 6.00 & 13.00 & 6.00 & 0.70711 & 6.00 & 13.00 & 6.00 & 0.70711 \\
\hline MorSlez & 4.00 & 8.00 & 4.00 & 2.82843 & 3.00 & 7.00 & 3.00 & 2.12132 & 3.00 & 7.00 & 3.00 & 2.12132 \\
\hline Jihozápad & 6.00 & 13.00 & 6.00 & 2.12132 & 8.00 & 16.00 & 8.00 & & 7.00 & 15.00 & 7.00 & 0.70711 \\
\hline $\begin{array}{l}\text { Střední } \\
\text { Morava }\end{array}$ & 6.00 & 13.00 & 6.00 & 2.12132 & 6.00 & 12.00 & 6.00 & 1.41421 & 6.00 & 13.00 & 6.00 & 2.12132 \\
\hline
\end{tabular}

Source: Author's own work

Also, the suspension of financial flows from EU funds to the ROP Severozápad because of a suspicion of corruption, which occurred in 2011, highlights the increased risk in this region. Greater improvements, however, were made in the Prague and Jihozápad regions. Since 2010, Prague has been one of the two regions to establish a regional anti-corruption strategy. It also seeks to fight against conflict of interest by means of regularly updated codes of conduct for councillors and officials. The Jihomoravsko region is the second region in the Czech Republic which created its own anti-corruption strategy, in 2011. Also in the evaluation of the transparency of public tenders of the non-profit organisation Oživení, the Jihovýchod region ranked second to Prague and in the assessment of the issue of conflict of interest even overtook Prague and was rated as the best region struggling with this issue.

From the assessment of the Czech Republic within the RIC in 2010, it is clear that the value of the index at the national level is considerably worsened by the Prague region. Also, the Jihovýchod and Severozápad regions reached a value lower than the Czech Republic as a whole. These three regions are ranked in the overall scale below the national assessment and can be expected to impair the national assessment of corruption in the Czech Republic as a whole. In the RIC evaluation from 2013, the Prague cohesion region is still below the national values of the RIC, although it has significantly improved its score, as has the Severozápad region and now the Moravskoslezsko region. In the monitored period 2010-2013, these regions were identified as regions affected by corruption more than other regions in the Czech Republic. It can therefore be assumed that the reduction of corruption in these regions would improve the assessment of the Czech Republic as a whole in the context of existing indices at the national level of corruption. 
Tab. 5: Regional Index of Corruption for 2010 and 2013 in the regions of the CR

\begin{tabular}{c|c|c|c|c} 
& NUTS & RIC 2010 & NUTS & RIC 2013 \\
\hline & Czech Republic & -0.8554 & Czech Republic & -0.7947 \\
\hline 1 & Prague & -1.5486 & Severozápad & -1.2304 \\
\hline 2 & Jihovýchod & -0.9193 & MorSlez. & -1.1510 \\
\hline 3 & Severozápad & -0.8958 & Prague & -1.0085 \\
\hline 4 & Stř. Čechy & -0.8588 & Stř. Čechy & -0.7340 \\
\hline 5 & MorSlez. & -0.7876 & Stř. Morava & -0.6699 \\
\hline 7 & Stř. Morava & -0.7296 & Jihovýchod & -0.5734 \\
\hline 8 & Severovýchod & -0.6218 & Severovýchod & -0.5715 \\
\hline
\end{tabular}

Source: Author's own work

\section{Conclusion}

In the text of this paper, the Regional Corruption Index, RIC, was proposed which, based on data from the World Bank and the European Commission, allows the level of corruption at the level of cohesion regions to be quantified. The proposed index uses extensive surveys of knowledgeable institutions which deal with corruption in the long term and takes into account not only regional assessments of respondents living in a certain region, but also the national assessment of experts. It is an index that at present enriches the existing expert assessment with the views of the population in the cohesion regions, who are the users of public goods and services in the region.

With the use of a Regional Corruption Index, RIC, the regional level of corruption of all Member States of the European Union and some candidate countries was also calculated. The resulting RIC value demonstrated that some European Union countries show a very high degree of variability at the regional level of corruption. This confirms the assumption that existing indices evaluating the national level of corruption can ultimately overestimate regions more affected by corruption and vice versa underestimate those less corrupt. Among the Member States with a very high variability of corruption within the cohesion regions are Italy, Romania and Bulgaria. Also in the Czech Republic, different corrupt activity was confirmed within individual cohesion regions. The region most affected by corruption according to the
RIC of 2010 was the Prague cohesion region; according to the evaluation of the RIC of 2013 it was the Severozápad region. Both these indices showed the region least affected by corruption to be the Jihozápad region.

The authors of this paper believe that the new methodology for quantifying corruption at the sub-national level has the potential for broad theoretical and practical applications. Besides theoretical, scientific-research analysis leading to the definition of deviations in the regional level of corruption from the level of corruption at the national level, applying the RIC could allow the mutual comparison of individual sub-national levels of a country in terms of the degree of corruption and become a new tool for identifying the variability and intensity of corruption in a given area. Practically, it would help define problem areas of a given region and facilitate direct identification of anti-corruption initiatives. In this context, it is interesting that according to the last Anti-Corruption Report published by the European Commission, the Czech Republic, in drawing money from EU funds for the period 2007-2013, was rated the worst in the entire European Union. One of the key problems of drawing resources from European funds is particularly corruption. European funds so often, paradoxically, do not help remove undesirable regional disparities, but the distribution of those resources has been proven to increase opportunities for corruption, which brings additional negative economic consequences to the region, which may result in disparities within the country increasing [3]. 
At the current level of knowledge, the ability to quantify the extent of corruption at a subnational level fills a gap that, within the general issue of corruption still exists, both in the Czech Republic and worldwide. Exposing corruption in today's globalised environment is becoming more complex and it is an issue even for countries that generally achieve relatively good results. It is therefore necessary to continue charting corruption and prevent its further expansion. The present article only opens another direction of scientific research in this field. It can be assumed that extending the time scale will allow the Regional Corruption Index, RIC, further research in this area, especially with regard to the need for a practical application of the proposed methodology at the level of authentic regions.

This paper was created within the project SGSFES Scientific Research in Economic Policy and Administration. Project registration number 2014002.

\section{References}

[1] BECK, P. J., MAHLER, M. W. A Comparison of Bribery and Bidding in Thin Markets. Economics Letters. 1986, Vol. 20, pp. 1-5. ISSN 0165-1765. DOI: 10.1016/0165-1765(86)90068-6. [2] DEL MONTE, A., PAPAGNI, E. The Determinants of Corruption in Italy: Regional Panel Data Analysis. European Journal of Political Economy. 2007, Vol. 23, pp. 379-396. ISSN 0176-2680.

[3] EUROPEAN COMISSION. Anti-corruption report 2014 [online]. EC, 2014 [cit. 2014-0620]. Available from: http://ec.europa.eu/dgs/ home-affairs/what-we-do/policies/organizedcrime-and-human-trafficking/corruption/anticorruption-report/index_en.htm.

[4] EUROPEAN COMISSION. Measuring Quality of Government and Sub-National Variation. Regional Policy [online]. EC, 2011 [cit. 2013-09-09]. Available from: http://ec.europa. eu/regional_policy/sources/docgener/studies/ pdf/2010_government_1.pdf.

[5] FIORINO, N., GALLI, E., PETRARCA, I. Corruption and Growth: Evidence from the Italian regions. European Journal of Government and Economics. 2012, Vol. 1, No. 2, pp. 126-144. ISSN 2254-7088.

[6] FRIČ, P. a kol. Korupce na český způsob. 1. vyd. Prague: Nakladatelství G plus G, 1999. ISBN 80-86103-26-9.
[7] HALÁSKOVÁ, M., HALÁSKOVÁ, R. Administrative Territorial Structures in EU Countries and their Specifics. Scientific Papers of the University of Pardubice, Series D, Faculty of Economics and Administration. 2009, Vol. 15, pp. 62-71. ISBN 978-80-7395-234-1.

[8] HUNTINGTON, S. P. Political Order in Changing Societes. New Haven: Yale University Press, 1968. ISBN 0-300-01171-7.

[9] CHMELÍK, J. Pozornost, úplatek a korupce. Prague: Linde Prague, 2003. ISBN 80-7201434-X.

[10] CHRÁSKA, M. Metody pedagogického výzkumu. Prague: Grada Publishing, 2007. ISBN 978-80-247-1369-4.

[11] KAUFMANN, D., KRAAY, A. and MASTRUZZI, M. Governance Matters IV: Governance Indicators for 1996-2004 [online]. [cit. 2014-06-20]. Available from: http://siteresources.worldbank.org/INTRES/ Resources/469232-1107449512766/ GovMattersIV_main.pdf.

[12] LEFF, N. H. Economic Development through Bureaucratic Corruption. Political Corruption-A Handbook. Iss. 5. New Brunswick: Transaction Publisher, 1989. ISBN 0-88738163-4.

[13] LEITE, C., WEIDMANN, J. Does Mother Nature Corrupt - Natural Resources, Corruption and Economic Growth [online]. Washington: International Monetary Fund, 1999 [cit. 201406-20]. IMF Working Paper No. 85. Available from: http://www.imf.org/external/pubs/ft/ wp/1999/wp9985.pdf.

[14] LIEN, D. H. D. Asymmetric information in competitive bribery games. Economics Letters. 1987, Vol. 23, Iss. 2, pp. 153-156. ISSN 01651765. DOI: 10.1016/0165-1765(87)90029-2.

[15] LUI, F. T. An Equilibrium Queuing Model of Bribery. Journal of Political Economy. 1985, Vol. 93, Iss. 4, pp. 760-781. ISSN 0022-3808.

[16] MAURO, P. Corruption and Growth. Quarterly Journal of Economics. 1995, Vol. 110, No. 3, pp. 681-712. ISSN 0033-5533. DOI: $10.2307 / 2946696$.

[17] MAURO, P. The Effects of Corruption on Investment, Growth and Government Expenditure [online]. Washington: International Monetary Fund, 1996 [cit. 2014-06-20]. IMF Working Paper No. 98. Available from: http://www. imf.org/external/pubs/ft/wp/1996/wp0098.pdf.

[18] MINISTERSTVO VNITRA ČR. Strategie vlády v boji proti korupci na období let 2013 a 2014 [online]. Praha: MVČR, 2013 [cit. 2014- 
04-20]. Available from: http://www.mvcr.cz/ clanek/boj-proti-korupci-strategie-vlady-v-bojiproti-korupci.aspx.

[19] MINISTERSTVO VNITRA ČR. Vládní program boje proti korupci [online]. Praha: MVČR, 2006 [cit. 2014-04-18]. Available from: http:// kormoran.vlada.cz/usneseni/usneseni_webtest. nsf/0/37116E873678ACFFC12571B6006D4474.

[20] NYE, J. S. Corruption and Political Development: A Cost-Benefit Analysis. The American Political Science Review. 1967, Vol. 61, Iss. 2, pp. 417-427. ISSN 0003-0554. DOI: http://dx.doi.org/10.2307/1953254.

[21] POLICIE ČR. Statistické přehledy kriminality [online]. Praha: PČR, 2014 [cit. 201405-18]. Available from: http://www.policie.cz/ statistiky-kriminalita.aspx.

[22] SVAZ PRŮMYSLU A DOPRAVY ČR. Šetření v krajích [online]. SPADČR, 2013 [cit. 2014-04-18]. Available from: http://www.spcr.cz/ ankety/setreni-v-krajich-2013.

[23] TANZI, V., DAVOODI, H. Corruption, Growth and Public Finances [online]. Washington: International Monetary Fund, 2000 [cit. 2014-06-20]. IMF Working Paper 00/182. Available from: http://www.imf.org/external/ pubs/ft/wp/2000/wp00182.pdf.

[24] TANZI, V., DAVOODI, H. Corruption, Public Investment, and Growth [online]. Washington: International Monetary Fund, October 1997 [cit. 2014-06-20]. IMF Working Paper 97/139. Available from: http://www.imf.org/external/ pubs/ft/wp/wp97139.pdf.

[25] TARANTOLA, S., SALTELLI, A. Composite indicators: the art of mixing apples and oranges. Statistisches Bundesamt [online]. 2008 [cit.
2015-03-04]. Available from: http://kolloq. destatis.de/2007/abstr_ueb.htm;\%20http:// kolloq.destatis.de/2007/tarantola.pdf. ISSN 1653-8919.

[26] THE QUALITY OF GOVERNMENT INSTITUTE. From Aland to Ankara: European Quality of Government index [online] University of Gothenburg, 2013 [cit. 201403-09]. Available from: http://www.qog.pol. gu.se/digitalAssets/1455/1455551_2013_11_ charron.pdf. ISSN 1653-8919.

[27] TRANSPARENCY INTERNATIONAL. Corruption Perceptions Index 2012 [online]. TI, 2013 [cit. 2013-03-07]. Available from: http://cpi. transparency.org/cpi2012/.

[28] VOLEJNÍKOVÁ, J. Transparentnost ekonomického prostředí nových členských států EU a alokace PZI. E+M Ekonomie a Management. 2006, Vol. 9, Iss. 2, pp. 15-34. ISSN 1212-3609.

[29] VOLEJNÍKOVÁ, J. Korupce v ekonomické teorii a praxi. Prague: Professional Consulting, 2007. ISBN 978-80-7259-055-1.

Ing. et Ing. Veronika Linhartová, Ph.D. University of Pardubice

Faculty of Economics and Administration Institute of Economic Sciences veronika.linhartova@upce.cz

doc. Ing. Jolana Volejníková, Ph.D. University of Pardubice

Faculty of Economics and Administration Institute of Economic Sciences jolana.volejnikova@upce.cz 


\section{Abstract}

\section{QUANTIFYING CORRUPTION AT A SUBNATIONAL LEVEL}

\section{Veronika Linhartová, Jolana Volejníková}

Regarding the fact that bribery and other methods of corruption are illegal in most countries, their participants try to hide them very carefully and uncovering corruption is often almost impossible. Despite that a high number of specific procedures exist nowadays. A common feature of these methods is however that they focus on the corruption rate at the level of countries. Quantification of the corruption rate in smaller regional areas is still a considerably unexplored territory not only in the Czech Republic but also all over the world. Also the definition of the potential impacts of corruption or their precise quantification is an area that was investigated only in general level of state. Detailed analysis of corruption still lacks regional dimension. Subnational distinction of a territory in terms of the corruption rate could provide a completely new extension of theories of reasons and consequences of regional disparities. There are several reasons why to focus on this issue. Perhaps the strongest reason is that if corruption is one of the variables that have an effect of reducing economic performance, the elimination of corruption in certain regions may be the key to the elimination of regional economic disparities and thus increase the economic performance of the state.

The main goal of the presented article is formulated in this connection. It consists of a proposal of a methodology for quantifying the corruption rate in individual regions of the Czech Republic. It will be possible to mutually compare individual regions and at the same time define the rate of deviation of a region from "surface" corruption rate in a country. Definition of these regional disparities in corruption will be a benefit mainly for anti-corruption policies of a country.

Key Words: Corruption, region, regional disparities, Transparency International, Corruption Perception Index.

JEL Classification: D73, H11.

DOI: 10.15240/tul/001/2015-2-003 